\title{
Siedem gór, siedem strumieni. Wiersze o sensie istnienia
}

Góra i strumień - jakiż potencjał kryje się za tymi wyobrażeniami! Skalisty pejzaż, majestat niebotycznych grani, ich zarys na tle nieba, obłoki zakrywające szczyt, srebrzysty blask strumienia sączącego się spod paproci, ze źródła wytryskującego ku słońcu w szczelinach błękitu... Majestat i wdzięk, trwanie opoki i taneczne migotanie uciekającej strugi. Byt niewzruszony, stały i zmienne, ruchliwe jestestwo. Moc niezmiennego i metamorfoza płynności, stabilna przestrzeń i przeciekający czas: nogi stoją mocno na skale, palce nie mogą uchwycić przepływającej wody.

W tradycji kulturowej wielu ludów góra jest jednym z najmocniejszych symboli, nacechowanym różnorodnymi znaczeniami. Słownik symboli literackich podaje wiele przykładów symbolicznych konotacji góry: niewzruszenie, stałość, światło, centrum świata, siedziba bogów, wróżek, droga do nieba, raju, czyśćca, piekła, objawienie, zmartwychwstanie, miejsce pielgrzymek, kultu, pokój, swoboda, medytacja, arcydzieła, osiągnięcia, ciąża, kobieta, płodność, młodość, czystość. Góry szczytami sięgają nieba, a podstawą dotykają piekła, łączą więc w sobie sfery sacrum i profanum. Niejednokrotnie w mitologiach kosmologicznych u stóp góry wytryskuje źródło, bierze początek strumień, rozlewający życiodajne wody po ziemi. Kosmiczna góra jest środkiem świata i jego osią, łączącą ziemię z niebem. Tworzy mandorlę, przecięcie się kół nieba i ziemi, scalając w sobie przeciwstawne elementy: afirmację i negację, dobro i zło, miłość i nienawiść.

Symboliczne konotacje strumienia wpisują się w szersze znaczenie rzeki. Rzeka według wspomnianego słownika symbolizuje barierę, przeszkodę, wtargnięcie, niebezpieczeństwo, powódź, strach, potwora, stratę, łaskę Bożą, zejście do piekieł, wyrocznię, obronę, pomoc, słońce, twórczość, życie, śmierć, zasadę żeńską, płodność, zmartwychwstanie, wytchnienie, odrodzenie, zapomnienie, upływ czasu. Jest to symbol ambiwalentny, gdyż odpowiada twórczej sile natury i zmiennego pierwiastka temporalnego.

Połączenie obrazu góry i strumienia przywołuje niemalże automatyczne skojarzenie z górskim pejzażem. Wody wytryskujące spod skat, krasowe potoki, siklawy, wywierzyska, ponory i źródła stanowią najpiękniejsze fragmenty krajobrazu gór. 
Urzekające piękno prowokuje artystów; góry z ich strumieniami i źródłami stanowią częsty motyw w sztuce, także w poezji. Poeci nie opiewają wszakże jedynie urody skalnych pejzaży, lecz w inspiracji nimi szukają głębszego sensu, sięgającego korzeni ludzkiego istnienia i namysłu nad jego istotą.

Jednym z uporczywie powracających motywów utworów poetyckich, które zostały zainspirowane obrazami góry i strumienia, jest wędrówka. Przywołuje ona obraz człowieka przemierzającego swoje życie niczym wędrowiec wspinający się na szczyt. Góry stają się tutaj rozbudzającym wyobraźnię obrazem wędrówki ludzkiego ducha, stworzonego i powołanego, aby wznosić się z ziemi ku wyżynom niebios. Jest to wędrówka w górę, wznoszenie się ku sferze sacrum; istnieje wszakże też kierunek odwrotny, wraz z toczącym swoje wody nurtem strumienia: ku nizinom, wrotom piekielnym, ujściu do morza stanowiącego kres istnienia rzeki, rozpływającej się w kołysanych falami przepastnych głębinach.

Wymowny obraz nachylenia ludzkiego życia ku niepewności bytu (którego reprezentantem jest strumień), ale zarazem solidności jego egzystencji (zobrazowanej w odwołaniu się do krajobrazu gór) znajdziemy w wierszu Joanny Ślósarskiej (2016):

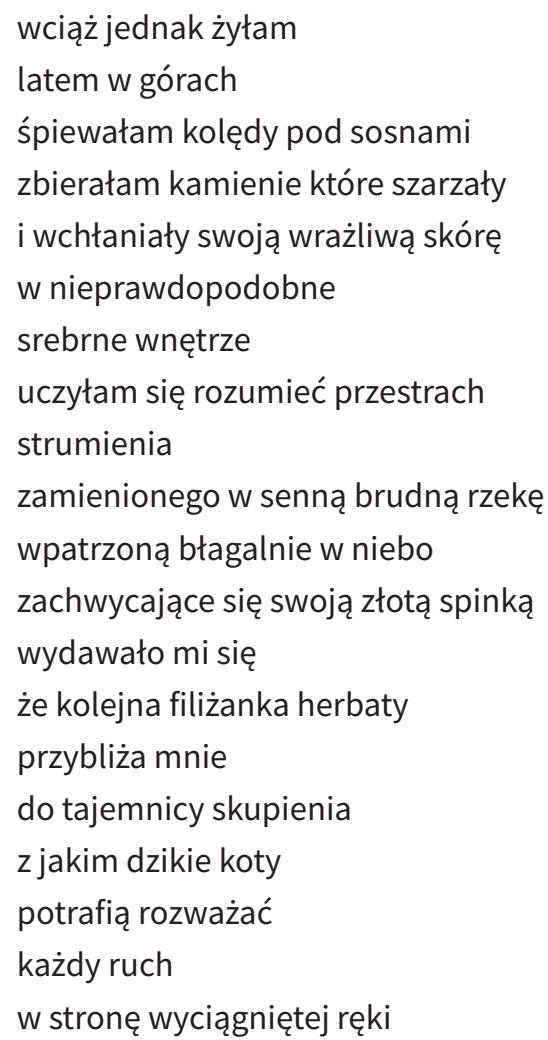


Podmiot liryczny wiersza porusza się po istniejącym świecie niepewnie, jakby trochę nieporadnie, na pewno ze zdziwieniem i potrzebą poznania tego, co jest istotą bytu; świadczą o tym sformułowania typu: „uczyłam się”, „,wydawało mi się”. Zastanawia określenie użyte na początku wiersza: „wciąż jednak żyłam”, przywołujące uporczywość trwania, jakby na przekór czemuś. Czemu? Być może wbrew upływającemu czasowi? Na przekór śmierci? Taka zastygła w wiecznej formie egzystencja jest podtrzymywana przez trwające góry i lato; te pierwsze przywołują skojarzenie z czymś stałym, niezmiennym, solidnym w swojej skalistej materii, letnia pora roku to zaś czas pełni, dojrzałości, rozkwitu w najbujniejszej formie. Oto więc mamy obraz istnienia uporczywego, wciąż się odradzającego, pomimo jego równoczesnej kruchości i niepewności. Ulotność życia przywołują wyjęte z wody, zbierane przez podmiot liryczny kamienie, połyskujące i piękne w chwili, gdy obmywa je woda, a za chwilę szarzejące, wchłaniające swoją urodę w „nieprawdopodobne srebrne wnętrze".

W wierszu odnajdziemy również przywołanie mrocznej strony egzystencji, ujęte w wizję „sennej brudnej rzeki”, w którą powoli, niepostrzeżenie zamienia się górski strumień, zstępujący z gór ku dolinom. Przestrach strumienia, nieubłaganie przeistaczającego się w leniwie płynące, zanieczyszczone koryto rzeczne, staje się także doświadczeniem podmiotu lirycznego, dostępującego łaski zrozumienia i empatii, a zarazem nieuchronności i grozy upływu czasu. Nie ma ucieczki przed misterium przemijania, nie pomoże błagalne wpatrywanie się w niebo, odwoływanie się do jakiejś cudownej interwencji z wysokości, gdyż niebo wobec przepływającej rzeki i upływającej ludzkiej egzystencji zachowuje niewzruszony spokój, a nawet obojętność, zajęte kontemplacją swojej „złotej spinki”. Niebiański dar kontemplacji, umiejętność osiągnięcia „tajemnicy skupienia” nie jest dany ani rzece, ani podmiotowi lirycznemu; mają go jedynie dzikie koty, będące nieokiełznaną emanacją życia w najczystszej, nieskażonej żadną tęsknotą formie.

Wiersz Joanny Ślósarskiej wzbudza nieokreślony żal w czytelniku; nieokreślony, bo niewyrażony dosłownie, a jednak przewijający się podskórnie, będący doświadczeniem podmiotu lirycznego, udzielającym się odbiorcy. Podmiot liryczny bezskutecznie pragnie posiąść tajemnicę egzystencji, podpatrując życie kamieni, rzeki i kotów, ale nie jest w stanie jej zrozumieć ani osiągnąć spokoju i pewności, które mogłyby być dane w mistycznym poznaniu istoty bytu.

Smutek istnienia odczuwany przez człowieka w chwili ogarnięcia przez niego refleksyjnym spojrzeniem tworów natury, nostalgia nieokreślona, acz dokuczliwa, stają się także udziałem podmiotu wypowiadającego z wiersza Kazimierza Przerwy-Tetmajera (1902): 


\section{We mgtach strumienie}

We mgłach strumienie szumią wód

po skale biegnąc ściętej;

we mgłach wieczorny opadł chłód

na sennych fal odmęty;

we mgłach żałobny pomrok z hal

i ciemnych zszedł krzesanic -

i we mgłach spływa żal, ach, żal

bez dna, bez dna, bez granic...

Górskie strumienie i skały, po których toczą one swe wody, krzesanice i hale otula mgła, będąca zapowiedzią nadchodzącej nocy. Przywołuje ją „wieczorny chłód” oraz „senne odmęty”, kojarzące się z porą mroku. W przeciwieństwie do wiersza Ślósarskiej w utworze Przerwy-Tetmajera nie odnajdziemy metaforycznego obrazu pełni ludzkiego życia, lecz jedynie impresję odnoszącą się do jakiegoś jego fragmentu, związanego z przeżywaną aktualnie żałobą i żalem. Po czym? Z jakiego powodu? Nie jest to określone jednoznacznie, możemy domyślać się, że żal „bez dna, bez granic” związany jest z utratą czegoś (lub kogoś), co było cenne. Mgła skutecznie rozmywa wszelkie kontury, zaciemnia widzenie, uniemożliwia poznanie; mamy jedynie sugestywny opis udzielającego się żalu, nieokreślonej tęsknoty, nostalgii spływającej w dolinę mroku.

Mgła rozmiękcza pejzaż, zacierając trwałość i solidność skał, a zarazem dając ujście żalowi otulającemu ziemię niczym mglisty całun; solidność i niezmienność gór oraz ich stałość zostają zastąpione chwilową impresją, trwającą tak krótko jak tuman, który może zniknąć wraz z pierwszymi promieniami porannego słońca. Na razie jednak sytuacja opisana w wierszu budzi nie tylko smutek, ale i niepokój. Mamy tu do czynienia z sytuacją wędrówki materii w dót: strumienie wód biegną po ściętej skale, wieczorny chłód opada, pomrok schodzi z hal i smutek spływa we mgłach. Jest to schodzenie z wyżyn ku temu, co ziemskie, a może i piekielne; z pewnością nie jest to ścieżka biegnąca do raju - ta wiodłaby w przeciwnym kierunku, ku górskim szczytom. Droga została określona jasno, prowadzi w jednym kierunku i nie pozostawia możliwości wyboru.

Taką możliwość - wyboru trudnego, bo nieokreślonego do końca - stawia przed czytelnikiem podmiot liryczny w wierszu Zbigniewa Herberta (1997): 


\section{Ścieżka}

Nie była to ścieżka prawdy lecz po prostu ścieżka

z rudym korzeniem w poprzek igliwiem po boku

a las pełen jagód i duchów niepewnych

nie była to ścieżka prawdy bowiem nagle

traciła swoją jedność i odtąd już w życiu

cele nasze niejasne

Na prawo było źródło

jeśli wybrać źródło szło się po stopniach mroku

w coraz głębszą ciemność wiódł na oślep dotyk

do matki elementów którą uczcił Tales

by w końcu się pojednać z wilgotnym sercem rzeczy

z ciemnym ziarnem przyczyny

Na lewo było wzgórze

dawało ono spokój i pogląd ogólny

granicę lasu jego ciemną masę,

bez poszczególnych liści pnia poziomki

kojącej wiedzy że las

jest jednym z wielu lasów

Czy naprawdę nie można mieć zarazem

źródła i wzgórza idei i liścia

i przelać wielość bez szatańskich pieców

ciemnej alchemii zbyt jasnej abstrakcji

Podmiot liryczny zastrzega na samym początku wiersza, że nie mamy w nim do czynienia ze „ścieżką prawdy”, lecz ze zwyczajną leśną dróżką, jakich wiele - jej pospolitość przywołuje obraz „rudego korzenia” i „igliwia”, a także trasa wiodąca przez jagodowy zagajnik. Jednak nagle ten realistyczny opis zostaje zmącony wprowadzeniem pomiędzy jagodowe krzewinki ulotnej, niewidzialnej egzystencji „duchów niepewnych”. Czy to ich obecność powoduje, że biegnąca do tej pory przez las swojska ścieżka nagle „traci swą jedność”, rozwidlając się w dwóch kierunkach, biegnących - co znamienne - w prawą i lewą stronę, w dół i w górę? Na rozstaju trzeba dokonać wyboru, w którym kierunku podążyć. 
Na prawo jest źródło i dróżka wiodąca ku niemu schodzi „po stopniach mroku” w „coraz głębszą ciemność”, tak że w końcu nic nie widać i idący nią w dół wędrowiec musi polegać już nie na zmyśle wzroku, lecz dotyku. W ten sposób można dotrzeć do źródła, czyli do „matki elementów”, do „ciemnego ziarna przyczyny”; przywoływany w wierszu Tales z Miletu wywodził wszak swoją filozofię istnienia i jego pierwotnej przyczyny z wody, z której wszystkie byty biorą swój początek.

Na lewo prowadzi ścieżka biegnąca ku wzgórzu, z którego emanującego spokojem szczytu zobaczyć można las jako pejzaż, bez rozróżnienia pojedynczych bytów drzewa, pnia, poziomki czy liścia, które w sumie składają się na ogólny widok lasu jako „jednego z wielu lasów”. Z tej perspektywy las staje się nie tyle konkretnym skupiskiem drzew, krzewów i ziót, ile platońską ideą lasu; idealną formą: „ciemną masą", znajdującą swoje odbicie w materialnym świecie.

Wędrowiec postawiony w sytuacji opisanej w wierszu musi dokonać wyboru, ale nie wie dokładnie jakiego, gdyż szybko spostrzega, że żadna ze ścieżek nie jest idealna. Pierwsza zawiedzie go ku poznaniu szczegółów, druga zaś przyniesie mu ogólną wiedzę o świecie. Poeta ubolewa nad gorzką prawdą, że nie ma żadnej nici łączącej oba kierunki poznania. Podmiot liryczny w wierszu zadaje dramatyczne, nierozstrzygnięte pytanie: „Czy naprawdę nie można mieć zarazem źródła i wzgórza, idei i liścia"? Każdy człowiek w swoim życiu dochodzi w pewnym momencie do brzemiennego w konsekwencje momentu wyboru: czy oddać się metafizycznemu zgłębianiu początku wszystkiego, podążyć ścieżką duchowego rozwoju, poszukiwania sensu istnienia, czy wybrać drogę wiedzy empirycznej, zgłębiając prawa rządzące materią, uznać naukę za jedyną dyscyplinę, która może wyjaśnić mechanizm funkcjonowania świata. Dramatyzm wyboru podkreślony jest dobitnym stwierdzeniem, że wybór tylko jednej ścieżki nie doprowadzi nas do prawdy. Czy więc całkowite poznanie jest niemożliwe i nawet „szatańskie piece alchemii” niczego tu zmienić nie mogą?

Ciekawe jest, że przywołana w wierszu droga duchowa, szukająca źródła, prowadząca ostatecznie do „pojednania z wilgotnym sercem rzeczy”, wiedzie w dót. W wierszach ślósarskiej i Przerwy-Tetmajera ścieżka biegnąca z gór ku dolinom wiązała się raczej z upadkiem ducha, ugrzęźnięciem w sferze materii skażonej śmiercią i smutkiem, natomiast w wierszu Herberta schodzenie po „stopniach mroku" jest uwieńczone odkryciem przyczyny istnienia. Weźmy jednak pod uwagę, że owo schodzenie tak naprawdę nie wiedzie wędrowca w dół, lecz „w głąb” (w „coraz głębszą ciemność”). Każdy poszukiwacz duchowej ścieżki rozwoju wie, że prowadzi go ona w głąb jego jestestwa, na drodze medytacji i kontemplacji jednoczącej duszę z Duchem. Znacząca jest także przywołana w wierszu symbolika 
źródła, do którego wiedzie ścieżka: oznacza ono prawdę, mądrość, oczyszczenie, odnowę, pragnienie, siłę życiową, jest obrazem duszy (jako źródło życia wewnętrznego). Dla chrześcijan jest ono także prototypem sakralnego zdroju zbawienia, który wytryskuje z przebitego boku Chrystusa na krzyżu. Źródło może być także obrazem sity twórczej, poszukiwanej przez każdego artystę.

Tym razem więc to ścieżka biegnąca w mrok i niepewność wydaje się tą właściwą, pomimo że ogląd ze szczytu wzgórza przynosi wędrowcom rzekomy „spokój” i „kojącą wiedzę”. Jest to jednak wiedza martwa; idea lasu nigdy nie będzie żywym leśnym organizmem, pulsującym w rytmie szmeru zielonego krwiobiegu liści.

Obraz wędrówki po ścieżkach życia, duchowej pielgrzymki pomiędzy niebem i ziemią przynosi także kolejny wybrany przeze mnie do analizy wiersz autorstwa Adama Zagajewskiego (2010):

\section{Żarliwe pstrągi}

Rzeka płynęła wolno jak modlitwa starego mnicha.

Zanurzyłem się w jej monotonny nurt,

Czując, że każde imię staje się tak przejrzyste.

„Wszystko już było - szepnąłem do siebie - wszystko już się wydarzyło,

Dlatego nie można przerwać wiecznej pielgrzymki”.

Delirium tremens zachwytu przeszywało moją ostrożną duszyczkę.

I nagle ustyszałem chór żarliwych pstrągów,

Które radośnie podążały do obcych krain,

Pozdrawiając góry, źródła, błękity.

Rzeka płynie wolno, oferując nam wędrówkę, która nie skończy się szybko. Płynie tak powoli jak modlitwa starego mnicha, która przywołuje duchowy aspekt podróży, podkreślony także przez metaforę „wiecznej pielgrzymki”. Zanurzenie się podmiotu lirycznego w „monotonnym nurcie” jest równocześnie jego zgodą na przemijanie, na pokorne przyjęcie stwierdzenia, że „wszystko już było”. W umyśle odbiorcy od razu pojawia się skojarzenie z powiedzeniem przypisywanym Heraklitowi z Efezu: panta rhei - wszystko płynie, byty są zmienne, istnienie nietrwałe. Jesteśmy pielgrzymami, jednymi z wielu, a wszyscy podążamy wraz z nurtem rzeki w jednym kierunku - ku nieznanym nam „obcym krainom”. Nasze wyjątkowe i jedyne życie, nasza wędrówka tak osobista i pełna przeżyć doświadczanych tylko przez nas włącza się w cykl kolejnych pokoleń ludzkości. Jednak każdy z nas ma prawo do nadawania znaczenia swoim cierpieniom i swojemu szczęściu; pomimo wspólnoty człowieczego losu każde istnienie jest niepowtarzalne, osobiste, jednostkowe. 
Podmiot liryczny doświadcza „delirium tremens zachwytu” - jest to jednoczące uczucie przeciwstawnych sobie emocji; zachwyt przywołuje piękno wędrówki w nurcie rzeki, delirium tremens kojarzy się z koszmarem obezwładniającego strachu wobec zagrożenia czyhającego w wodzie, nawet jeśli jest ono jedynie wytworem zwiedzionego umysłu. Zapewne dlatego duszyczka podmiotu lirycznego jest tak ostrożna. Życie niesie nam różne doświadczenia, zarówno radosne, jak i przerażające; trzeba być czujnym, aby nie kusić losu.

Duchowa pielgrzymka człowieka przebiega, jak stwierdził kiedyś Zagajewski, pomiędzy biegunami nieba i ziemi, a ludzki umysł potrzebuje obu tych przestrzeni, gdyż ich poznawanie prowadzi do odpowiedzi na pytania o sens życia i twórczości jako jego najwyższego spełnienia. Twórczość, mówi poeta, to żarliwość - „płomienny śpiew świata, na który odpowiadamy własnym, niedoskonałym śpiewem”.

Dlatego w ostatnich wersach wiersza wybucha hymnem „chór żarliwych pstrągów”. Ich wędrówka w nurcie rzeki jest pełna radości, chociaż podążają ku obcym krainom - wszak życie nasze kryje nieznaną nam przyszłość, a to, co po śmierci, tym bardziej osłania tajemnica. Mimo tej niepewności pstrągi wychwalają w tryumfalnym śpiewie ziemię („góry”), niebo („błękity”) i życie („źródło”).

Egzystencja człowieka, zdają się mówić nam pstrągi z wiersza Zagajewskiego, pomimo swej kruchości i zmienności losu, jest godna radosnego hymnu śpiewanego przez wędrowca, a zadaniem poezji jest ukazywanie piękna życia w jego różnorodnych przejawach.

Zagajewski opiewa urodę życia, nie zastanawiając się nad jego genezą. Elementami składowymi ludzkiego bytu są radość i smutek, euforia i cierpienie, delirium tremens i piękno. Po prostu są, istnieją jako nieodłączny człon egzystencji. Ale jak je pojąć, jak wytłumaczyć? Jak pogodzić ze sobą upajające piękno życia i śmierć? Ten dylemat zaprząta Czesława Miłosza w wierszu Nad strumieniem (2011):

\section{Nad strumieniem}

Szmer przezroczystej wody na kamieniach

w jarze pośrodku wysokiego lasu.

Jaśnieją w słońcu paprocie na brzegu,

piętrzy się nieogarniona forma liści

lancetowatych, mieczykowatych,

sercowych, łopatowatych,

językowatych, pierzastych,

karbowanych, ząbkowanych,

piłkowanych - i kto to wypowie.

I kwiaty! Białawe baldachy, 
modre kielichy, jaskrawożółte gwiazdy,

różyczki, grona.

Siedzieć i patrzeć

na ujawnianie się trzmieli, loty ważek, podrywanie się muchołówki, w plątaninie łodyg pośpiech czarnego żuka.

Wydaje mi się, że słyszę głos demiurga:

„Albo nieme skały jak w pierwszym dniu stworzenia, albo życie, którego warunkiem śmierć, i to upajające ciebie piękno”.

Od pierwszych strof wiersza podmiot liryczny ogląda z ujawniającym się coraz większym zachwytem pleniący się nad strumieniem bujny świat flory. Brakuje słów dla określenia różnorodności roślinnych form liści i kwiatów, zachwyt odejmuje mowę, skłania ku zamilknięciu i kontemplacji w ciszy piękna stworzenia. Jest ono niczym rajski ogród, pełen wyszukanych form „jaśniejących w słońcu”. A jednak gdzieś pod powierzchnią sielskiego opisu czai się mrok, skryty w „plątaninie łodyg”, przywołany przez „pośpiech czarnego żuka”. Gdzie on się tak spieszy, czyżby uciekał przed podrywającą się do lotu muchołówką? Na tle zielonego kobierca ujawniają się latające owady: bzyczące trzmiele, topocące skrzydłami ważki; spokój materii roślinnej zostaje zburzony. Ludzkie oko siedzącego nad strumieniem obserwatora nie tylko biernie kontempluje piękno przyrody, lecz także komentuje jej porządek, harmonię zakłóconą pojawieniem się dynamicznie latających owadów i ptaka, który zapewne podrywa się do lotu, aby na nie zapolować.

Zakłócenie harmonii, zburzenie porządku piękna wzywającego do biernego zachwytu wpisuje się w porządek stworzenia świata przez demiurga, przywołany w ostatnich strofach wiersza: warunkiem życia jest śmierć, skrywająca się pod cielesną postacią piękna. Świat nieruchomy, niepodlegający przemianom, nieśmiertelny, byłby możliwy, gdyby powołany został do istnienia jedynie w formie przyrody nieożywionej. Skały pojawiające się w wierszu są nieme, a ich forma jest taka sama jak w pierwszym dniu stworzenia. Kiedy wytryska strumień, jego wody dają możliwość wyłaniania się z nich coraz bardziej skomplikowanych form życia, ale ich zaistnienie wiąże się z równoczesnym pojawieniem się cierpienia i śmierci. Taki jest Boży plan, Jego odwieczny zamyst. Jak powiedział Miłosz, komentując twórczość swojego kuzyna, mistyka i poety Oskara Miłosza: „akt Stworzenia jest równoczesny z Ukrzyżowaniem i każda chwila życia na ziemi jest zadanym sobie cierpieniem Boga”. 
W wierszu Miłosza nie mamy do czynienia z wędrówką podmiotu lirycznego w sensie fizycznym, ale z wędrówką myśli, dokonującej przejścia od obserwacji ku filozoficznej refleksji nad istotą życia powołanego do istnienia dzięki miłości Boga do Jego stworzenia.

Refleksja nad twórczym działaniem Boga stwarzającego świat i człowieka pojawia się jako główny motyw w wierszu Strumień autorstwa Jana Pawła II, pochodzącym z Tryptyku rzymskiego (2003):

\section{Strumień}

Ruah

Duch Boży unosit się nad wodami...

\section{Zdumienie}

Zatoka lasu zstępuje

w rytmie górskich potoków

ten rytm objawia mi Ciebie,

Przedwieczne Słowo.

Jakże przedziwne jest Twoje milczenie

we wszystkim, czym zewsząd przemawia

stworzony świat...

co razem z zatoką lasu

zstępuje w dół każdym zboczem...

to wszystko, co z sobą unosi

srebrzysta kaskada potoku,

który spada z góry rytmicznie

niesiony swym własnym prądem...

- niesiony dokąd?

Co mi mówisz górski strumieniu?

w którym miejscu ze mną się spotykasz?

ze mną, który także przemijam -

podobnie jak ty...

Czy podobnie jak ty?

Pozwól mi się tutaj zatrzymać -

pozwól mi się zatrzymać na progu,

oto jedno z tych najprostszych zdumień.)

Potok się nie zdumiewa, gdy spada w dół

i lasy milcząco zstępują w rytmie potoku 
- lecz zdumiewa się człowiek!

Próg, który świat w nim przekracza,

jest progiem zdumienia.

(Kiedyś temu właśnie zdumieniu nadano imię „Adam”.)

Był samotny z tym swoim zdumieniem

pośród istot, które się nie zdumiewały

- wystarczyło im istnieć i przemijać.

Człowiek przemijał wraz z nimi

na fali zdumień.

Zdumiewając się, wciąż się wyłaniał

z tej fali, która go unosiła,

jakby mówiąc wszystkiemu wokoło:

„zatrzymaj się! - masz we mnie przystań”

„we mnie jest miejsce spotkania

z Przedwiecznym Słowem" -

„zatrzymaj się, to przemijanie ma sens”

„ma sens... ma sens... ma sens!”

\section{2. Źródło}

Zatoka lasu zstępuje

w rytmie górskich potoków...

Jeśli chcesz znaleźć źródło, musisz iść do góry, pod prąd.

Przedzieraj się, szukaj, nie ustępuj, wiesz, że ono musi tu gdzieś być -

Gdzie jesteś, źródło?... Gdzie jesteś, źródło?!

Cisza...

Strumieniu, leśny strumieniu, odsłoń mi tajemnicę swego początku!

(Cisza - dlaczego milczysz?

Jakże starannie ukryłeś tajemnicę twego początku.)

Pozwól mi wargi umoczyć

w źródlanej wodzie

odczuć świeżość,

ożywczą świeżość. 
Czytelnik oddający się lekturze poematu ma niewątpliwie natychmiastowe skojarzenie z opisem świata zawartym w Księdze Rodzaju: Bóg stwarza ziemię, rośliny i zwierzęta, a następnie powołuje do życia człowieka, który odczuwa podobieństwo egzystencjalne do górskiego strumienia, przemijającego tak samo jak on, i do otaczających go zwierząt - a zarazem czuje się od nich odrębny, samotny ze „swoim zdumieniem". Potok się nie zdumiewa, spadając kaskadą w dót, nie zdumiewa się las „zstępujący w rytmie potoku”, nie zdumiewają się inne istoty stworzone przez Boga. Im wystarcza bezrefleksyjne istnienie podporządkowane przemijaniu, które ich nie boli, nie obchodzi. Człowiek wyodrębnia się spośród innych bytów tym, że potrafi się zdumiewać, zadumać nad przemijaniem, nad sensem istnienia. Czy przemijanie ma sens? Tak podpowiada człowiekowi przyroda w swych ożywionych i nieożywionych formach, odsłaniając mu arenę spotkania z „Przedwiecznym Słowem": wieczysta przystań istnieje, jest ukryta w Słowie, które opisał Jan w swojej Ewangelii: „Na początku było Słowo, a Słowo było u Boga, i Bogiem było Słowo. Ono było na początku u Boga. Wszystko przez Nie się stało, a bez Niego nic się nie stało, z tego, co się stało". Dlatego echo obudzone w odwiecznym górskim pejzażu powtarza zdumionemu i trwożącemu się człowiekowi: „zatrzymaj się, to przemijanie ma sens, ma sens... ma sens... ma sens!”.

Odczucie przemijania, zdolność zdumiewania się, refleksji nad swoim życiem oraz umiejętność odnajdywania swojego Stwórcy w świecie to pierwotne doświadczenie człowieka, znane już Adamowi. Człowiek ma zdolność do zatrzymania się w biegu życia, podjęcia nad nim refleksji, do przeżywania świadomie swojej egzystencji, w przeciwieństwie do strumienia, lasu i innych stworzeń, którym wystarczy sama egzystencja. Istota ludzka ma umiejętność poznania tej rzeczywistości, która ją przekracza, jest w stanie poprzez doświadczenie świata odnaleźć w niej jego Stwórcę. Wymaga to jednak podjęcia wysiłku. Wszystkie nieświadome stworzenia, jak strumień czy las, schodzą rytmicznie z gór ku dolinom: „stworzony świat... razem z zatoką lasu zstępuje w dół każdym zboczem”. Ten rytm objawia Boga, ale owo objawienie dostrzega jedynie człowiek, stworzony na Jego obraz i podobieństwo. Człowiek podejmujący wysiłek zrozumienia sensu życia, odnalezienia swojego Stwórcy, musi podążać w odwrotnym kierunku: ku górze, „pod prąd”, szukając źródła. Czym ono jest? Gdzie jest? Trzeba go szukać, „przedzierając się”, „,nie ustępując". Wędrowiec wyruszający w tę drogę zmuszony jest do podjęcia wysiłku i ryzyka; trzeba zaryzykować trud, a nawet cierpienie. Jednak tylko taka duchowa wędrówka powiedzie do początku i zarazem kresu istnienia, doprowadzając człowieka do Boga, odpowiadając na pytania o sens życia i jego kresu.

Podobną wymowę ma kończący refleksję o poetyckich metaforach strumienia i góry niepublikowany wiersz autorki niniejszej analizy. Ponownie wędrówka 
zaproponowana przez podmiot wypowiadający wiedzie w górę, przez zimowy pejzaż, wolny od oznak życia, pod prąd rzecznego nurtu, „tam gdzie wody się z pneumą obłoków mieszają", do początku stworzenia, do źródła życia wiecznego, symbolizowanego przez paprocie, „które nigdy nie więdną”. Tym źródłem jest, tak jak w poemacie Jana Pawła II, Bóg, początek i sens istnienia, Kreator stwarzający świat, ostateczna odpowiedź na pytania o znaczenie wszystkiego, o samotność, o przemijanie, o istotę bycia człowiekiem.

Tak tu cicho i mroku kolebka na wietrze

Kołysze senne wiatry niebieskie od cienia

Płaszcz ziemi surowy, zgrabiały na mrozie, muśnięty

Pożogą słońca na niebie północno-zachodnim,

Tak tęskno. I nie ma już ptaków

Wytchnienie do wiosny ma pejzaż od drżenia trzepotem

Skrzydełek, od śpiewu w zatracenia studni,

Od bitew podniebnych na brzmienia z kryształu skowronków

Twoja ręka, co kreśli nieboskłonu pętlę

Wywodzi z wrót niebytu krajobrazów supły

Rzeko, struno wody, żyło cierpkiej ziemi,

Rzeko, pręgo cienia, zanurzenie w ciszy,

Rzeko, wywołujesz podziemne pierścienie

Czarnych wód, co początkiem są bytu i kresem

Twa ręka, odcisk Mistrza, dłuto Kreatora

Wyciosuje szlak w górę, pod prąd, tam gdzie chmury

Wypiętrzają się z gardła mrocznego wąwozu

Rzeko, co wskroś nurtu prowadzisz ku chmurom,

Tam gdzie wody się z pneumą obłoków mieszają,

Tam, gdzie pierwszej materii nie dotknęło skażenie;

Rzeko, kiedy odsłonisz jądro tajemnicy:

Źródło pośród paproci, co nigdy nie więdną?

Ten wiersz, symbolicznie siódmy (bo siódemka to pełnia i doskonałość), kończy nasze podpatrywanie poetyckiego zmagania się z opisami sensu życia. Doskonatymi obrazami ludzkiej egzystencji, pojemnymi w symboliczne konotacje, są góry 
i strumienie przywołujące motyw wędrówki: z nurtem strumienia w dół lub w górę - pod prąd, ku niebu. Dobór wierszy i ich usytuowanie wiedzie nas od metafor niepewności życia i niemożności uchwycenia tajemnicy egzystencji, poprzez nieokreślony żal towarzyszący traceniu w życiu tego, co cenne, przez dylemat wyboru duchowego rozwoju lub wiedzy, radosne celebrowanie życia bez zastanawiania się nad jego istotą, aż do uchwycenia sensu ludzkiej egzystencji w zjednoczeniu z demiurgiem, kreatorem, Bogiem, który jest źródłem wszystkich sensów określających ludzki byt. Uchwyciwszy sens ostateczny, wracamy zaś ku niepewności, zdziwieniu i zachwytowi, bo one są początkiem każdego namysłu nad istotą rzeczy, zarówno tego o charakterze poetyckim, jak i naukowym.

Niniejszy esej nie ma charakteru stricte naukowego i jest to celowy zamiar jego autorki. W ten sposób pragnie ona wyrazić swoją aprobatę dla szerokiej formuły spotkań przyjętych przez Polskie Stowarzyszenie Strategii Twórczych w ramach poszukiwania różnorodnych strategii twórczych, w inspiracjach potencjałem natury, a zarazem dezaprobatę wobec zjawiska „punktozy” i ewaluacji naukowej, która nie ma nic wspólnego z prawdziwym uprawianiem nauki, szczególnie w obszarze humanistyki. Dlatego nie ma w tym eseju naukowego stylu ani takiejże konstrukcji, określonej metodologii ani źródłowych przypisów, nawet wtedy, gdy pojawiają się krótkie cytaty.

Natomiast z szacunku dla pracy innych, tych, których analizy były dla mnie inspiracją do snucia refleksji, zamieszczam poniżej krótką notę bibliograficzną.

\section{Bibliografia}

Herbert Z. (1997), Napis, Poznań: Wydawnictwo Dolnośląskie.

Jakóbczyk J. (2001), Kazimierz Przerwa-Tetmajer. Zblizenia, Katowice:Wydawnictwo Uniwersytetu Śląskiego.

Jan Paweł II (2003), Tryptyk rzymski, Kraków: Wydawnictwo Św. Stanisława BM.

Miłosz C. (2011), Wiersze wszystkie, Kraków: Znak.

Pismo Święte Starego i Nowego Testamentu, w przekładzie z języków oryginalnych (2013), opr. Zespół Biblistów Polskich, wyd. V, Poznań: Wydawnictwo Pallotinum.

Przerwa-Tetmajer K. (1902), Erotyki, Kraków: Księgarnia J. Czerneckiego.

Siwiec M.K. (2013), Zbigniew Herbert - twórca iźródło. Droga do źródła iźródło w wierszu „Ścieżka”, „Filo-Sofija”, nr 22(3), s. 105-130.

Ślósarska J. (2016), Rebis. Wiersze wybrane, Łódź: Wydawnictwo Primum Verbum.

Zabawa K. (2014), Studnia, strumień, źródło - obrazy-symbole w "Pieśni o blasku wody" Karola Wojtyły i w "Tryptyku rzymskim” Jana Pawła ll, [w:] Ł. Burkiewicz, P. Duchliński, J. Kucharski (red.), Oblicza wody w kulturze, Kraków: Akademia Ignatianum, Wydawnictwo WAM, s. 173-190.

Zach J. (2014), Jak myśli wiersz? Czesław Miłosz: „Nad strumieniem”, „Poznańskie Studia Polonistyczne. Seria Literacka”, nr 24(44), s. 243-254.

Zagajewski A. (2002), Obrona żarliwości, Kraków: Wydawnictwo a5.

Zagajewski A. (2010), Wiersze wybrane, Kraków: Wydawnictwo a5. 